\title{
Transformasi Genetik Tanaman Kentang (Solanum tuberosum L.) dengan Gen acvB Menggunakan Vektor Agrobacterium tumefaciens
}

\author{
DARWIN SILALAHI*), I GEDE PUTU WIRAWAN, DAN MADE SRITAMIN \\ Program Studi Agroekoteknologi Fakultas Pertanian Universitas Udayana \\ Jl. PB. Sudirman Denpasar, Bali 80232 \\ ${ }^{*}$ E-mail: dsilalahi331@gmail.com
}

\begin{abstract}
Agrobacterium tumefaciens Mediated Genetic Transformation of acvB Gene in Potato (Solanum tuberosum L.). Genetic transformations are now routinely applied to plant mediated by Agrobacterium tumefaciens as the most convenient technique. This study aimed to prove the success of $A$. tumefaciens mediated genetic transformation in potato. $A$. tumefaciens LBA ( $p B I$ 121) and explant of potato shoot were used in this study. Explants were grown in vitro on Murashige and Skoog media. Transformation was implemented using smear technique by smearing A. tumefaciens to injured explant. Experimental groups consisted of two groups: control group which did not receive transformation treatment and treatment group receiving transformation treatment. Explant growth was observed through the presence of shoots, branches and the shoot height. Explants in the treatment group resulted in a higher number of shoots, branches, and shoot heights compared to control. Phenol compounds appear in explant epidermal tissue, indicating the wounds produced by A. tumefaciens infection, thus the gene predicted to be transformed. Identification by PCR is needed to prove the existence of the acvB gene in potato plants genome, using acvB specific PCR primer as the marker, such as (5'-CCCT CTAG AGAC CCGC GCCA AGGCG-3') and (5'CGCG TCGA CCTT GTCG GAAAG -3') with 540-bp in base pair size produced.
\end{abstract}

Keywords: in-vitro, transformation, smear technique, acvB

\section{PENDAHULUAN}

Transformasi genetik digunakan secara luas untuk mempelajari fisiologi, genetik dan perkembangan biologi tanaman. Agrobacterium tumefaciens banyak sekali digunakan untuk melakukan transformasi genetik tanaman. Transformasi dengan bakteri ini mempunyai keuntungan diantaranya adalah efisiensi transformasi tinggi, jumlah salinan gen sedikit yang tersisip ke dalam genom tanaman, dan dapat 


\section{DARWIN SILALAHI et al. Transformasi Genetik Tanaman Kentang (Solanum...}

mentransferkan gen berukuran besar(Hiei \& Komari, 2008).

Kentang merupakan tanaman pangan bernilai ekonomi tinggi yang dapat mendatangkan keuntungan bagi pengusaha industri makanan olahan, pedagang, dan petani yang membudidayakannya, sehingga tanaman kentang dianggap salah satu komoditas penting di dalam negeri dan diekspor. Mendukung pengembangan kualitas tanaman kentang diperlukan benih bermutu dan dalam program pembenihan kentang, penggunaan benih bebas patogen mutlak diperlukan. Benih tersebut dapat diperoleh melalui kultur jaringan disertai dengan pengujian patogen secara intensif dan dilanjutkan dengan teknik perbanyakan cepat secara in vitro.

Menurut Duriat (1987) upaya yang dapat dilakukan untuk meningkatkan produktivitas kentang dengan teknik mikropropagasi yaitu pemanfaatan teknik kultur jaringan tanaman untuk perbanyakan tanaman. Keuntungan perbanyakan tanaman kentang melalui kultur jaringan dibandingkan dengan metode lain adalah dapat menghasilkan tanaman bebas penyakit (Nematoda parasit, mikoplasma, viroid, virus, dan jamur) serta membuat variasi genetik. Hal ini karena cendawan dan bakteri dapat berkembang dengan cepat dalam kondisi in vitro, sehingga hanya tanaman yang benar-benar bersih (bebas cendawan dan bakteri) yang dipelihara (Zulkarnain et al., 2005).

Kultur jaringan adalah suatu metode untuk memperbanyak tanaman dengan menggunakan bagian tanaman seperti protoplasma, sel, sekelompok sel, jaringan dan organ serta menumbuhkannya dalam kondisi aseptik atau steril hingga bagianbagian tersebut dapat berkembang dan beregenerasi menjadi tanaman lengkap (Gunawan, 1987).

Teknik ini sangat membantu dalam usaha mengeliminasi patogen (penyakit sistemik), dengan metode kultur jaringan dapat dipilih bagian-bagian atau sel-sel yang tidak mengandung patogen sistemik terutama virus dan menumbuhkan sel-sel (bagian) tanaman tersebut serta meregenerasikannya kembali menjadi tanaman sempurna dan sehat.

Gamborg dan Skyluk dalam Biondi \& Thorpe (1981) menyatakan bahwa keberhasilan dalam teknologi dan aplikasi metode kultur jaringan erat dengan penyediaan hara yang mencukupi dan sesuai dengan kultur sel ataupun jaringan. Hal yang terpenting dalam menentukan keberhasilan kultur jaringan, yaitu sterilisasi alat, kualitas eksplan, dan media kultur yang digunakan 
(Roca et al. 1978;Goodwin 1980) A. tumefaciens merupakan bakteri patogen yang banyak digunakan untuk memasukkan gen asing ke dalam sel tanaman untuk menghasilkan suatu tanaman transgenik. Secara alami, A. tumefaciens dapat menginfeksi tanaman dikotil melalui bagian tanaman yang terluka sehingga menyebabkan tumor (crown gall). Bakteri yang tergolong dalam gram negatif ini memiliki sebuah plasmid besar yang disebut plasmid-Ti yang berisi gen penyandi faktor virulensi penyebab infeksi bakteri ini pada tanaman. Untuk memulai pembentukan tumor A. tumefaciens harus menempel terlebih dahulu pada permukaan sel inang dengan memamfaatkan polisakarida yang akan digunakan untuk mengkolonisasi atau menguasai sel tanaman.

Rekayasa genetika digambarkan sebagai ilmu dimana karakteristik suatu organisme yang sengaja dimodifikasi dengan manipulasi materi genetik, terutama DNA dan transformasi gen tertentu untuk menciptakan variasi yang baru, dengan memanipulasi DNA dan memindahkannya dari suatu organiasme ke organisme lain (disebut teknik rekombinan DNA), memungkinkan untuk memasukkan sifat pada hampir semua organisme pada tanaman, bakteri, virus atau hewan.
Organisme transgenik saat ini diproduksi massal, seperti enzim, antibodi monoklonal, nutrient, hormon dan produk farmasi yaitu obat dan vaksin (Campbell, 1996).

Gen $a c v B$ merupakan gen virulen kromosom baru. Penelitian homologinya mengungkapkan bahwa homolog gen $a c v B$ berfungsi dalam A.tumefaciens dan tidak ditemukan dalam bakteri lainnya. A.tumefaciens mampu mentrasfer DNA ke dalam sel tanaman, sementara bakteri lain yang diuji dalam studi tidak mampu mentrasfer DNA ke dalam sel tanaman. Akibatnya, distribusi gen $a c v B$ yang seperti ini menunjukkan bahwa gen $a c v B$ terlibat dalam proses transfer DNA pada sel tanaman. Gen $a c v B$ digunakan sebagai indikator, oleh karena itu, perlu diadakan pengujian mengenai respon pada tanaman kultur kentang secara in vitro terhadap transformasi genetik dengan menggunakan A. tumefaciens.

Penelitian ini dilakukan untuk menghasilkan metode transformasi gen pada tanaman (Solanum tuberosum L.) dan menghasilkan tanaman kentang (Solanum tuberosum L.) transgenik melalui kultur in vitro yang membawa gen $a c v B$. Penelitian ini dapat memberikan sumbangan dalam ilmu pengetahuan mengenai Transformasi Genetik Kentang (Solanum tuberosum L.) 


\section{DARWIN SILALAHI et al. Transformasi Genetik Tanaman Kentang (Solanum...}

dengan Gen $a c v B$ melalui perantara $A$. dan tidak bergejala penyakit. Umbi tumefaciens.

didiamkan tumbuh dalam wadah, tunas yang tumbuh diambil untuk eksplan.

\section{BAHAN DAN METODE}

Penelitian ini dilaksanakan sejak Desember 2019 sampai Maret 2020. Penelitian di Laboratorium Sumberdaya Genetika dan Molekuler Universitas Udayana.

Alat yang digunakan dalam penelitian ini terdiri atas timbangan digital, magnetik stirrer, autoklaf, microwave/oven, Laminar Air Flow Cabinet, inkubator, mesin vortex, water bath, pestle, PCR tube, transiluminator UV, mesin elektroforesis, kertas parafilm, spatula, kertas label, kamera digital, gelas ukur, gelas beker, gelas labu erlenmeyer, botol kultur, pinset, gunting, skalpel, mortar, mikropipet, tissue, api bunsen, cawan petri, sentrifus, sprayer dan eppendorf (tabung mikro).

Bahan yang digunakan dalam penelitian ini terdiri atas eksplan yaitu jaringan meristem pada tunas umbi kentang, aquades, media LB, gellan gum, sucrosa, klorox 10\%, detergen, benlate, alkohol 70\%, natrium hipoklorit, Tween, Agarose, TAE $100 \mathrm{ml}$, Gen $a c v B$ pada DNA.

Sumber eksplan umbi kentang diambil dari Unit Sayur Mayur Perusahaan Daerah Provinsi Bali, umbi yang dipilih adalah besar

\section{Sterilisasi Eksplan}

Eksplan tanaman dimasukkan ke dalam klorox dengan mengaduk atau digoyang-goyangkan \pm 5 menit. Bilas eksplan tanaman ke dalam air steril dengan mengaduk \pm 1 menit. Dipindahkan eksplan tanaman ke dalam alkohol dengan mencelupakan eksplan selama 3 detik, dan disterilkan kembali ke dalam air steril. Eksplan yang sudah steril kemudian direndam dalam larutan betadine $(5 \mathrm{ml}$ aquades +1 tetes betadine) dan digoyanggoyangkan.

\section{Sterilisasi Alat dan Bahan dan Ruang Inokulasi}

Botol kultur, pinset dan cawan petri yang digunakan dicuci dengan bersih menggunakan detergen. Kemudian dikeringkan. Setelah kering cawan petri dibungkus rapi menggunakan kertas, pinset skapel dibungkus menggunakan aluminium foil, kemudian diautoclave selama 15 menit dengan suhu $121^{\circ} \mathrm{C}$. Ruang inokulum dan Laminar Air Flow yang akan digunakan dibersihkan dengan menyemprotkan 70\% keseluruh dinding dan alasnya kemudian 
LAF dikeringkan menggunakan tissue, sehingga homogen, kemudian di autoklaf 15 kemudian lampu ultraviolet dihidupkan dan menit pada suhu $121^{\circ} \mathrm{C}$.

didiamkan selama 30-60 menit.

\section{Pembuatan Media}

Untuk $100 \mathrm{ml}$, stock MS dibutuhkan 2,5 gr/ml, agar $1,5 \mathrm{gr} / 100 \mathrm{ml}$ dan $2 \mathrm{gr}$ sukrosa. Stock vitamin yang digunakan terdiri dari $100 \mathrm{mg} / \mathrm{ml}$ myoinositol, 10 $\mathrm{mg} / \mathrm{ml}$ thiamine- $\mathrm{HCL}, 1 \mathrm{mg} / \mathrm{ml}$ nicotinic acid, $1 \mathrm{mg} / \mathrm{ml}$ pyridoxine-H. Media LB agar dibuat dengan melarutkan 1,5 g agar dan 100 ml media LB cair dengan magnetik stirrer

\section{Kultur Bakteri A. tumefaciens}

Bakteri yang digunakan pada penelitian ini adalah Agrobacterium tumefaciens LBA (pBI $121+$ acvB) yang berasal dari kultur stok gliserol dengan suhu pendinginan $-80^{\circ} \mathrm{C}$. Bakteri dikulturkan pada media luria bertani (LB), yaitu media khusus untuk menumbuhkan gram negatif. Kultur diklakukan dengan menggunakan dua metode yaitu metode gores dan metode tusuk.

\section{Konstruksi gen}

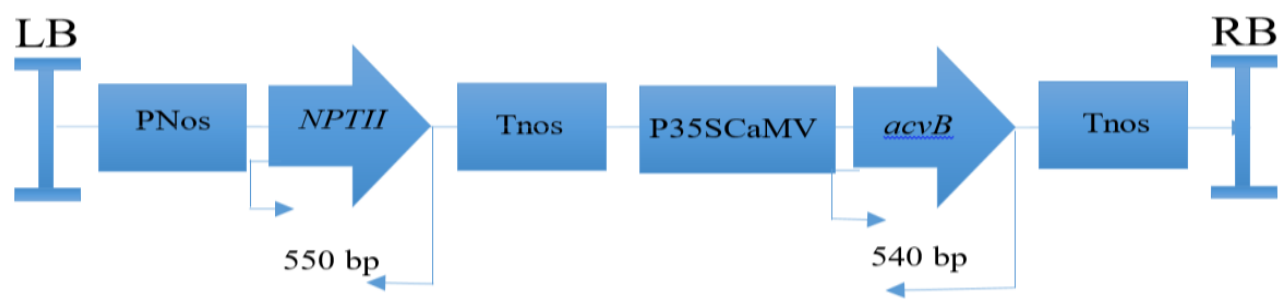

Gambar 1. Peta Konstruk T-DNA pada plasmid pBI $121-a c v B$.

Plasmid pBI 121-acvB dengan konstruk T-DNA mengandung left border (LB), promotor nopline synthase (PNos), neomycin phospotransferase (NPTII), terminator nopline synthase (TNos), promotor CaMV (P35SCaMV), acvB, dan right border $(\mathrm{RB})$ sebagai batas bagian $\mathrm{T}$ DNA.
Konstruk gen memiliki LB (left border) dan RB (right border) yang merupakan jembatan antar gen, setiap konstruk memiliki marka penanda yang berfungsi sebagai penanda bahwa indikator gen itu sudah masuk atau belum pada saat proses PCR yang menjadi penanda keberhasilan. Dalam konstruk penanda 


\section{DARWIN SILALAHI et al. Transformasi Genetik Tanaman Kentang (Solanum...}

terdapat dua gen, yaitu gen marka dan gen interest $(a c v B)$. Setiap gen mempunyai kaset sekuensing dari kaset awal (promotor) dan kaset sekuensing (terminator). NPTII (neomycin phospotransferase) digunakan karena menggunakan kanamisin, biasanya digunakan TNos (terminator nopline synthase) dan gen interest yang ada di Agrobacterium tumefaciens (gen $a c v B$ ) biasanya digunakan P35SCaMV (promotor CaMV) sebagai ketahanan tanaman dan penutup tetap menggunakan TNos (terminator nopline synthase).

\section{Transformasi Kentang dengan Gen $a c v B$}

Proses transformasi secara in vitro pada penelitian ini terdapat dua perlakuan yaitu (1) Eksplan yang tidak diinokulasikan dengan Agrobacterium tumefaciens, (2) Eksplan yang diinokulasikan dengan Agrobacterium tumefaciens. Eksplan di olesi dengan koloni A.tumefaciens, kemudian eksplan dicuci dengan air steril sebanyak 3 kali, selanjutnya eksplan yang diberi perlakuan ditanam pada media kultur in vitro yaitu media MS.

\section{Isolasi DNA A. tumefaciens}

Isolasi total DNA A.tumefaciens menggunakan DNA Mini Kit. Koloni bakteri yang sudah tumbuh dengan menggunakan metode tusuk diambil dari cawan petri dan ditumbuhkan pada $2 \mathrm{ml}$ media LB cair, kemudian inkubasi pada shaker dengan penggoyangan $10 \mathrm{rpm}$ selama 18-24 jam. Bakteri diinkubasi pada suhu $37^{\circ} \mathrm{C}$ dalam keadaan ruangan gelap. Bakteri yang berhasil tumbuh dipindahkan ke dalam eppendorf tube, lalu disentrifuge selama 5 menit dengan kecepatan 12.000 rpm dan dibuang supernatannya. Pellet yang ada ditambahkan $400 \mu \mathrm{l}$ GP1 buffer dan di vortex, kemudian diinkubasi pada $60^{\circ} \mathrm{C}$ selama 10 menit. Ditambahkan $100 \mu$ l GP2 buffer dan di vortex, kemudian ditambahkan $750 \mu 1$ GP3 buffer dan di vortex. Setelah semua tercampur kemudian didiamkan selama 5 menit. Disentrifuge selama 5 menit dengan kecepatan 14.000-16.000 rpm sampai terbentuk pellet pada eppendorf tube. Cairan yang terdapat pada eppendorf disebut supernatant dan dimasukkan pada GD colum dan ditambahkan $400 \mu \mathrm{l}$ W1 buffer serta di vortex. GD colum di tempatkan dalam collection tube, disentrifuge selama 5 menit dengan kecepatan 14.000-16.000 rpm. Dibuang cairannya dan GD colum ditempatkan pada eppendorf lalu ditambahkan $15 \mu$ l Elution buffer di tengah GD colum lalu didiamkan 3-5 menit. Disentrifugasi selama 3 menit dengan kecepatan 14.000-16.000 rpm. Cairan 
Agrotrop : Journal on Agriculture Science, 11 (1): 63 - 75 (2021)

sebanyak $15 \mu \mathrm{l}$ yang tertampung pada eppendorf tube adalah DNA dan di simpan pada suhu $-20^{\circ} \mathrm{C}$ (Wirawan \& Supartana, 2009).

\section{Pengamatan Tanaman Kentang Hasil} Kultur Jaringan secara in vitro secara visual

Transformasi tanaman kentang secara kultur in vitro diberikan dua perlakuan yaitu eksplan yang diinokulasikan dengan $A$. tumefaciens dan tidak diinokulasikan dengan A.tumefaciens, eksplan tersebut diamati selama 9 HST dan 20 HST, dimana eksplan tersebut menghasilkan jumlah tunas, jumlah cabang, dan tinggi tunas yang berbeda. Eksplan yang diinokulasi dengan bakteri terlihat bahwa ada fenolik di sekitar tempelan, dan eksplan yang tidak diinokulasi dengan bakteri tidak adanya fenolik.

\section{HASIL DAN PEMBAHASAN}

Pertumbuhan Bakteri A. tumefaciens pada Media LB

Hasil pengamatan yang telah dilakukan dalam tahap awal penelitian ini, dapat dilihat pada Gambar 2. bahwa pengamatan selama 48 jam ditemukan pertumbuhan koloni bakteri secara mengelompok dan koloni bakteri tunggal didapat pada alur goresan. Koloni bakteri tunggal yang tumbuh kemudian dipindahkan ke media LB yang baru untuk diperbanyak. Faktor-faktor lingkungan yang mempengaruhi pertumbuhan Agrobacterium adalah ketepatan nutrisi dan kesesuaian suhu. Brown (2006) mengatakan media luria bertani (LB) memiliki kandungan yeast ekstrak, $\mathrm{NaCl}$, tryotone dan $\mathrm{NaOH} 1 \mathrm{~N}$. Bakteri diinkubasi pada suhu $28^{\circ} \mathrm{C}-36^{\circ} \mathrm{C}$ selama 2-3 hari.
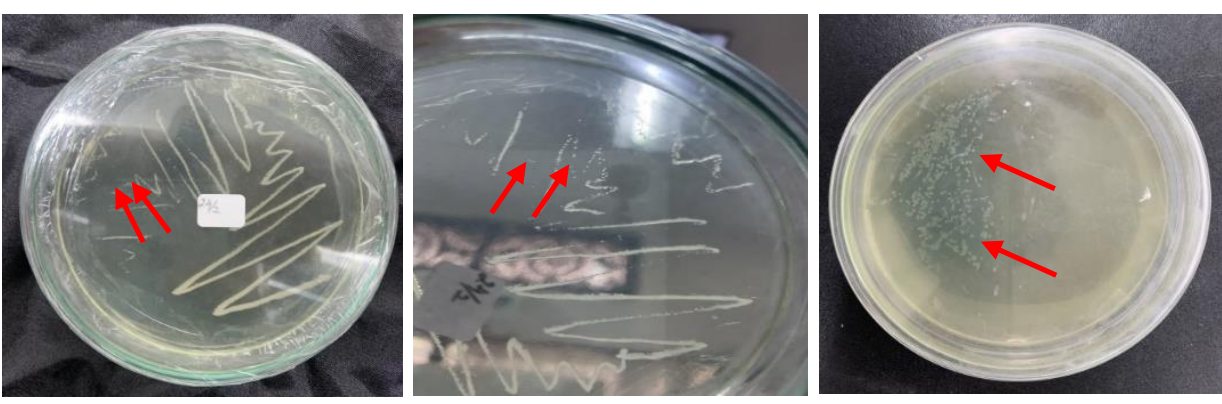

Gambar 2. Pertumbuhan koloni A.tumefaciens LBA (pBI $121+$ acvB) dengan Metode Gores. 


\section{DARWIN SILALAHI et al. Transformasi Genetik Tanaman Kentang (Solanum...}

Pertumbuhan A. tumefaciens pada (pBI $121+$ acvB) mempunyai ciri-ciri media LB terdapat 9 koloni yang telah berbentuk bulat, permukaan cembung, tepi disubkultur menggunakan metode tusuk dan berbentuk koloni tunggal yang tumbuh baik pada media LB padat. Manalu et al. (2014), menyatakan bakteri A. tumefaciens LBA koloni rata dan berwarna krem. Hal ini membuktikan adanya pertumbuhan $A$. tumefaciens yaitu pada media LB, dapat dilihat pada Gambar 3.

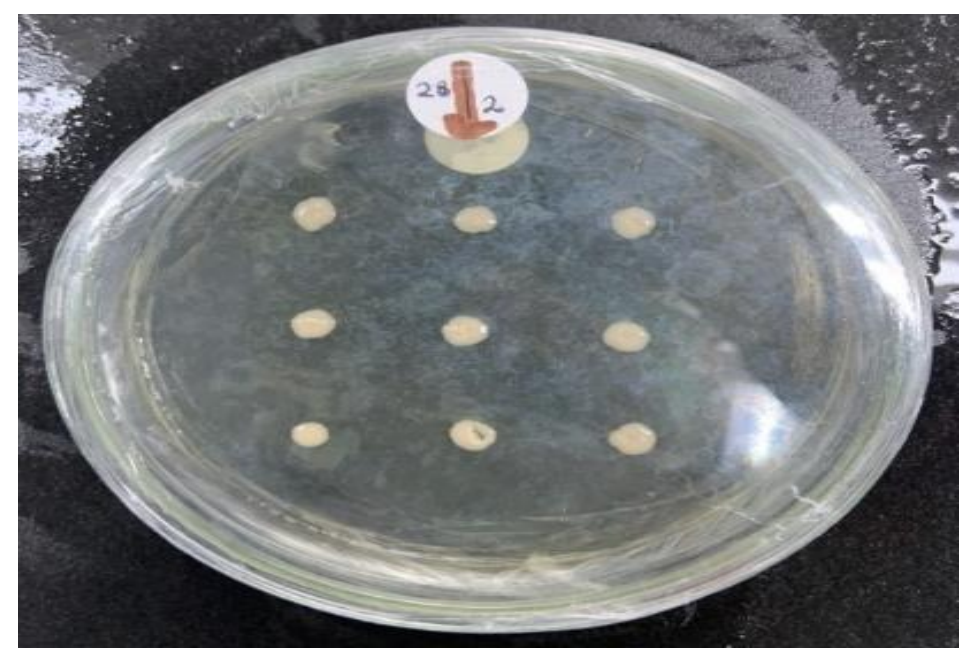

Gambar 3. Pertumbuhan koloni Agrobacterium tumefaciens LBA (pBI $121+$ acvB) pada media LB dengan menggunakan Metode tusuk

Bakteri yang tergolong kedalam gram negatif ini memiliki sebuah plasmid yang besar yang disebut plasmid-Ti yang membawa gen penyandi faktor virulensi penyebab infeksi bakteri ini pada tanaman. Untuk memulai pembentukan $A$. tumefaciens harus menempel terdahulu pada permukaan sel inang dengan memamfaatkan polisakarida yang dibutuhkan tanaman kemudia akan digunakan untuk mengkolonisasi atau menguasai sel tanaman (Silitonga et al., 2014).

\section{Hasil Isolasi Total DNA}

Hasil penyinaran di bawah lampu UV dapat dilihat pada Gambar 4. Pada penelitian ini konsentrasi gel agarose yang digunakan adalah $1 \%$ menggunakan larutan TAE $1 \mathrm{X}$. 


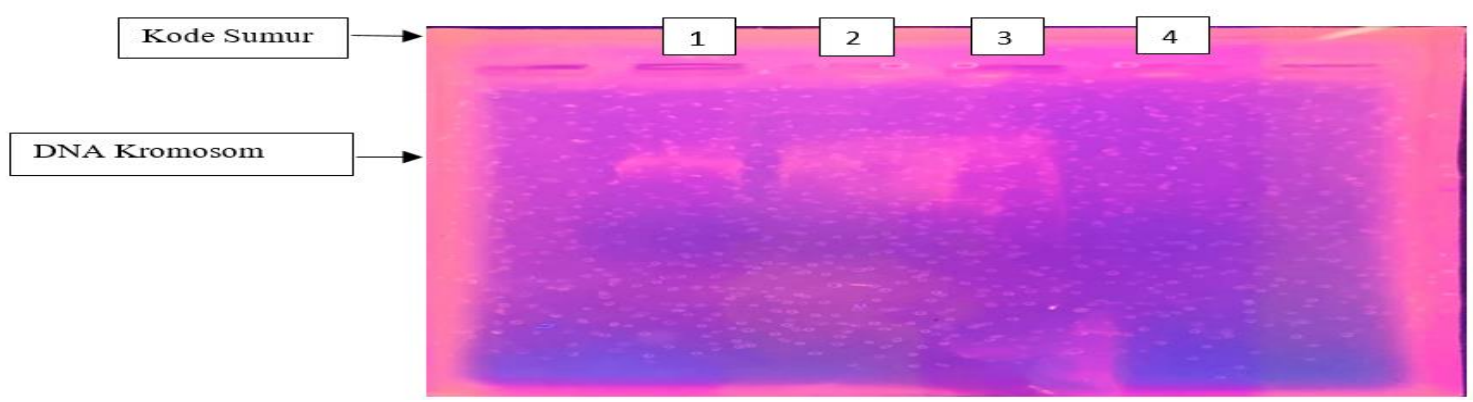

Gambar 4. Sumur 1,2,3 dan 4 merupakan hasil visualisasi total DNA bakteri Agrobacterium tumefaciens pada elektroforesis gel agarose $1 \%$.

Hasil isolasi pada sumur/well 1 bahwa

A. tumefaciens LBA (pBI $121+$ acvB) memiliki pita yang terlihat tebal dan jelas atau terang. Pita tebal dan terang secara kualitatif mengindikasikan konsentrasi hasil isolasi DNA yang dihasilkan tinggi. Hal ini membuktikan bahwa saat isolasi DNA kromosom tidak terikat pada buffer. Sedangkan pada sumur/well ke 2 dan 3 yaitu A. tumefaciens mempunyai ketebalan yang kurang pekat. Sehingga DNA terlihat blur atau kabur atau noise. Pita yang terlihat buram atau noise mengindikasikan konsentrasi DNA yang dihasilkan kecil. Dan pada sumur ke 4 yaitu A. tumefaciens LBA (pBI $121+$ acvB) tidak terlihat saat di elektroforesis, hal ini mengindikasikan bahwa kegagalan tersebut disebabkan karena stok bakteri yang ada tidak viable lagi.
Kultur Tanaman Kentang Hasil Transformasi Menggunakan Metode Kultur Tunas

Penelitian ini dilakukan dengan dua perlakukan yaitu (1) Eksplan yang tidak diinokulasikan dengan A. tumefaciens (kontrol), (2) Eksplan yang diinokulasikan dengan A. tumefaciens. Masing-masing menggunakan dua eksplan tiap perlakuan.seperti pada Gambar 5. Eksplan tersebut menghasilkan jumlah tunas, jumlah cabang, dan tinggi tunas yang berbeda. Penelitian ini dilakukan dengan dua perlakukan yaitu (1) Eksplan yang diinokulasikan dengan A.tumefaciens (kontrol), (2) Eksplan yang diinokulasikan dengan A. tumefaciens. Masing-masing menggunakan dua eksplan tiap perlakuan.seperti pada Gambar 5. Eksplan tersebut menghasilkan jumlah tunas, jumlah cabang, dan tinggi tunas yang berbeda. Berdasarkan Gambar 5. terlihat bahwa 


\section{DARWIN SILALAHI et al. Transformasi Genetik Tanaman Kentang (Solanum...}

pertumbuhan tunas eksplan A tidak pertumbuhan yang baik dikarenakan sudah memunculkan tunas dengan baik pada 9 memunculkan 3 tunas baru, sedangkan HST (Hari Setelah Tanam). Pada eksplan B eksplan D terlihat bahwa 4 tunas sudah sudah memunculkan tunas pada eksplan. tumbuh dengan baik.

Pertumbuhan eksplan $\mathrm{C}$ terlihat
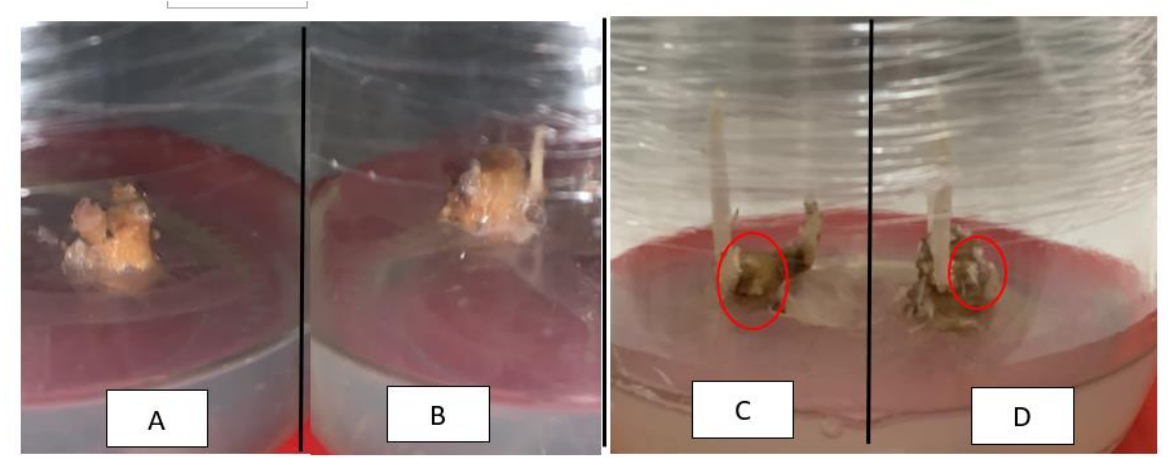

Gambar 5. Perkembangan eksplan tanaman kentang yang tidak diinokulasikan dan diinokulasikan dengan $A$. tumefaciens yang mengandung $a c v B$ di media seleksi yaitu media MS selama 9 HST. (A dan B) Eksplan yang tidak diinokulasikan dengan Agrobacterium pada media seleksi. (C dan D) Eksplan yang diinokulasikan dengan Agrobacterium dengan media seleksi

Pengaplikasian transformasi genetik dengan menggunakan Metode oles, yaitu dengan mengolesi satu koloni $A$. tumefaciens yang membawa gen $a c v B$ ke eksplan tanaman kentang selanjutnya dilakukan pengamatan pada tanaman kultur in vitro. Data ekspresi tersebut menunjukkan bahwa sebagian jaringan eksplan terinfeksi Agrobacterium (Gambar 5. pada C dan D yang dilingkaran merah) mengeluarkan fenolik yang menunjukkan bahwa infeksi diduga telah masuk dalam jaringan dan diindikasi bahwa gen itu juga masuk ke dalam sel tanaman. A. tumefaciens menempel pada eksplan kentang yang terluka karena tanaman tersebut mengeluarkan molekul sinyal berupa senyawa-senyawa fenolik, seperti acetosyringone. Senyawa-senyawa fenolik ini akan mengaktifkan gen vir yang terdapat di dalam Ti-plasmid, yang bertanggung jawab untuk mentransfer T-DNA dari $A$. tumefaciens menuju sel inangnya (tanaman). Pada tanaman dikotil, senyawasenyawa fenolik akan merangsang $A$. tumefaciens untuk menempel dan mentrasfer T-DNA. Sehingga untuk lebih lanjut untuk mengetahui teramplifikasi atau tidak gen 
tersebut yaitu dengan menggunakan tahap molekuler yaitu PCR (Polymerase Chain Reaction). Infeksi merupakan salah satu tahap dalam proses transfer gen dengan menggunakan Agrobacterium. Dalam proses infeksi, ruas T-DNA dipindahkan dari sel bakteri Agrobacterium ke dalam sel tanaman.

Fragmen DNA NPTII-Gus dipotong menjadi DNA satu rantai (ssDNA) yang kemudian pada ujung 5 'dari ssDNA tersebut berikatan protein virD2 dan virE2 menjadi selubungnya (coat protein). Kompleks DNA protein ini disebut T-kompleks yang akan bergerak, dimana pada protoplasma prion $a c v B$ akan berikatan pada kompleks ini dan mentransfernya keluar sel A. tumefaciens dan masuk kedalam sel tanaman. Pada plasmid pBI121, gen GUS diganti dengan gen $a c v B$. Keberadaan gen $a c v B$ berperan dalam proses transfer DNA kedalam sel inang.

Berdasarkan Gambar 6, eksplan tanaman kentang menghasilkan keberhasilan pertumbuhan yang berbedabeda. Pengamatan selama 20 HST terdapat kontaminan pada sumber eksplan kentang A yang disebabkan oleh bakteri. Sumber kontaminan yang disebabkan oleh bakteri menunjukkan ciri-ciri terbentuknya lapisan lendir berwarna putih dan lendir berwarna putih kecoklatan di bagian permukaan media yang terkontaminasi. Kontaminasi disebabkan oleh banyak hal salah satunya adalah kondisi laboratorium yang kurang steril. Selain itu tempat inkubasi yang dianggap bersih, sebenarnya tidak steril. Ditambah banyaknya mahasiswa sering membuka inkubator yang menyebabkan suhu pada inkubator tidak kontinyu. Eksplan B mengalami pertumbuhan tunas serta mengalami kontaminan pada media. Sedangkan pada eksplan C menunjukkan pertumbuhan tanaman dengan baik dan memperbanyak tunas yang baru, pada beberapa tunas tersebut mengalami perubahan warna pada ujung tunas menjadi kecoklatan (Browning) yang kemungkinan terjadi karena faktor cahaya, pencoklatan dapat berkurang dan dapat dihindari dengan perlakuan ruang gelap. Eksplan D menunjukkan fisiologi tanaman tumbuh dan berkembang dengan sangat bagus. 


\section{DARWIN SILALAHI et al. Transformasi Genetik Tanaman Kentang (Solanum...}
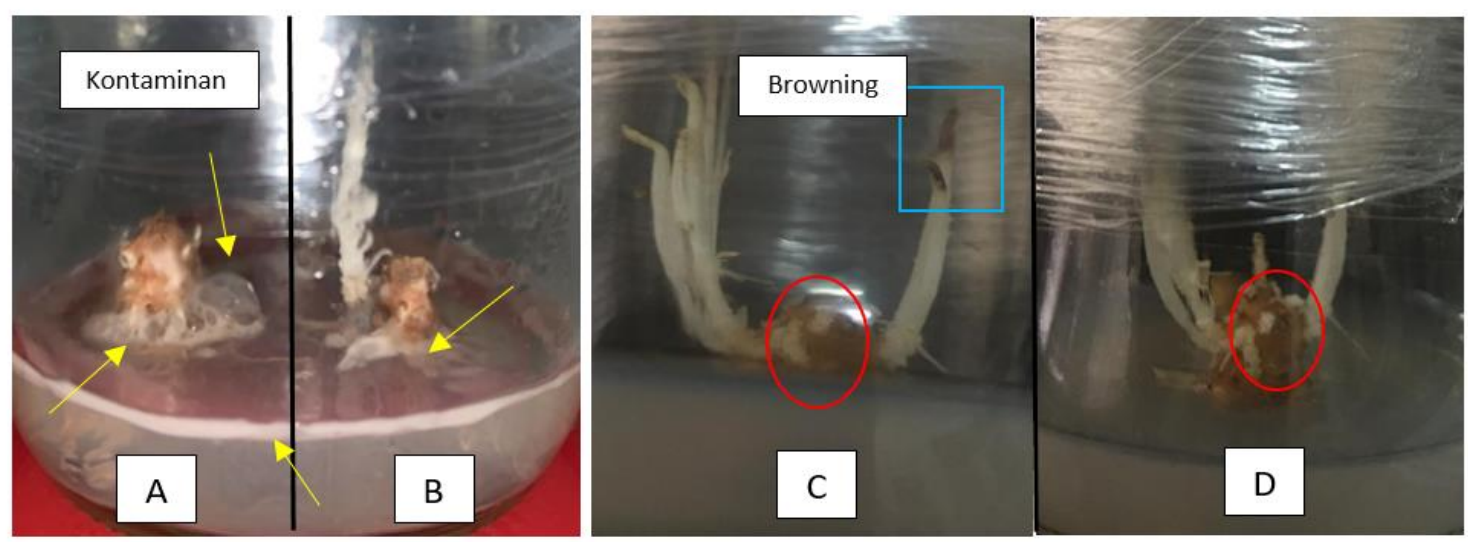

Gambar 6. Perkembangan eksplan tanaman kentang yang tidak diinokulasikan dan diinokulasikan dengan $A$. tumefaciens yang mengandung $a c v B$ di media seleksi yaitu media

MS selama 20 HST. (A) Eksplan yang mengalami kontaminan. (B) Eksplan tumbuh dan mengalami kontaminan (C) Ekplan tumbuh dan mengalami Browning (D) Eksplan tumbuh dengan baik

\section{SIMPULAN}

Kultur in vitro tanaman kentang (Solanum tuberosum L) dapat tumbuh dengan baik. Eksplan tanaman kentang yang ditanam pada media MS (Murashige and Skoog) menghasilkan jumlah tunas, jumlah cabang, dan tinggi tunas yang berbeda. Data ekspresi tersebut menunjukkan bahwa sebagian jaringan eksplan terinfeksi (A. tumefaciens) mengeluarkan fenolik yang menunjukkan bahwa infeksi diduga telah masuk dalam jaringan dan diindikasi bahwa transformasi telah terjadi. Eksplan yang diinokulasi dengan bakteri terlihat bahwa ada fenolik di sekitar tempelan, dan eksplan yang tidak diinokulasi dengan bakteri tidak adanya fenolik.

\section{DAFTAR PUSTAKA}

Biondi, S., \& Thorpe, T. A. (1981). Requirements for a tissue culture facility. In: Thorpe TA (Ed) Plant Tissue Culture - Methods and Applications in Agriculture. Academic Press.

Brown, T. A. (2006). Gene Cloning \& DNA analysis: An Introduction, 5th Edition. Wiley-Blackwell.

Campbell, P. O. Q. (1996). Super foods: agricultural products and genetic engineering. Biology Digest, 1(23), 10-17.

Duriat, A. S. (1987). Heat Treatment as a Mean Eliminating Potato Leaf Roll Virus from Seed of Potato. Prosiding Mes Elevstion Potato Seminar.

Goodwin, P. B. (1980). Methods for rapid propagation of potato. Paper Presented in the Symposium at Potato Production in the Tropic.

Gunawan, L. W. (1987). Teknik Kultur Jaringan Tumbuhan. Lab. Kultur Jaringan Tumbuhan. Lab. Kultur Jaringan Tumbuhan. Pusat Antar Universitas (PAU). Bioteknologi. 
IPB.Bogor.

Hiei, Y., \& Komari, T. (2008). Agrobacterium-mediated transformation of rice using immature embryos or calli induced from mature seed. Nature Protocols, 3(5), 824834. https://doi.org/10.1038/nprot.2008.46

Manalu, Y. H., Wirawan, I. G. P., \& Susrama, I. G. K. (2014). Isolasi dan Identifikasi Agrobacterium tumefaciens dari Tanaman Wortel (Daucus carota L.). Jurnal Agroekoteknologi Tropika (Journal of Tropical Agroecotechnology), 3(3), 119-127.

Roca, W. M., Espinoza, N. O., Roca, M. R., \& Bryan, J. E. (1978). A tissue culture method for the rapid propagation of potatoes. American Potato Journal, 55(12), 691-701. https://doi.org/10.1007/BF02852143

Silitonga, N., Wirawan, I. G. P., \& Susrama, I. G. K. (2014). Isolasi dan Identifikasi Agrobacterium Tumefaciens pada Tanaman Mawar (Rosa sp.). Jurnal Agroekoteknologi Tropika (Journal of Tropical Agroecotechnology), 3(3), 166-175.

Wirawan, I. G. P., \& Supartana, P. (2009). Bioteknologi Agrobacterium tumefaciens (Isolasi gen acvB, transformasi in planta dan produksi tanaman transgenic. Udayana University Press.

Zulkarnain, Ichwan, B., \& Astuti, R. (2005). Mikropropagasi kentang (Solanum tuberosum L.) cv. Granola: Pengaruh periode gelap pada awal kultur dan pengaruh konsentrasi kinetin pada kultur lanjutan. Jurnal Agronomi, 9(1), 5-8. 